\title{
The Creation of the Diocese of Bacolod in 1932
}

\author{
Miguel Avellaneda, OAR \\ Provincial Chronicler, Saint Nicholas of Tolentino Province, Spain \\ Translated and Annotated by \\ Emmanuel Luis A. Romanillos \\ Recoletos School of Theology, Quezon City, Philippines
}

\begin{tabular}{l} 
Article history: \\
Submitted: 4 October 2020 \\
Revised: 27 December 2020 \\
Accepted: 31 December 2020 \\
\hline Keywords: \\
Church history \\
Bishop Casimiro Lladoc \\
Diocese of Bacolod \\
Augustinian Recollects \\
Evangelization \\
Negros Island \\
Siquijor
\end{tabular}

\begin{abstract}
The creation of a mission territory evangelized for many decades or centuries by Augustinian Recollect missionaries into an apostolic vicariate or diocese was always an occasion for jubilation for them and the crowning glory of their efforts. This was the case of the Diocese of Bacolod in Negros Island, whose evangelization was entrusted to them in 1848. Thus the Recollect priests welcomed the good news and the arrival of the newly consecrated first local ordinary of Bacolod, Bishop Casimiro Lladoc, and his Manila entourage that included the Apostolic Delegate Guglielmo Piani, Bishop McCloskey of Jaro, and Father Leoncio Reta at Talisay parish church on 24 October 1933, earnestly urged parishioners to greet him along the way to the Recollect-built San Sebastian Cathedral and feted him with programs, speeches, and festive meals.
\end{abstract}

\subsection{Creation of the Diocese of Bacolod}

Through the apostolic constitution Ad Christi regnum of 15 July $1932,{ }_{1}^{1}$ Pope Pius XI created the Diocese of Bacolod, the capital of Negros Occidental, with the episcopal see at Bacolod and territories taken from the Jaro Diocese Iloilo and the Diocese of the Most Holy Name of Jesus in Cebu. The new ecclesiastical jurisdiction included the whole island of Negros, Siquijor, and the small islands on the eastern coast. Thus the Latin papal decree declares the four salient provisions:

1. A dioecesi Jarensi integram insulam vulgo Negros nuncupatam destrahimus una cum parculis insulis ad orientem adiacentibus. Item a Nominis Jesu seu Caebuana dioecesi, in praesens vacante, insulam Siquijor nuncupatam avellimus ac distrahimus. From the Diocese of Jaro, we take away the whole island, commonly known as Negros, together with the adjoining small islands in the east. We remove and separate from the Diocese of the Holy Name of Jesus or Cebu, sede vacante at present, together with the indicated island of Siquijor.

\section{Eregimus dioecesim de Bacolod. [...] We erect the Diocese of Bacolod. ${ }^{2}$}

\section{3. [...] Sedes in urbe Bacolod. The see is in Bacolod City.}

4. [...] Cathedra in ecclesia Sancti Sebastiani, in eadem urbe, cum grado et dignitate Ecclesiae Catholicae ... The seat is at San Sebastian Church in the same city with the rank and dignity of a Catholic church.

\subsection{Bishop Casimiro named First Bishop of Bacolod}

${ }^{1}$ The CBCP website for Bacolod Diocese declares that it was created on 16 May 1933. cf. http://www.cbcponline.net/jurisdictions/ bacolod.html. Accessed 3 December 2015. Then its CBCP news dated 28 January 2008, it gives another date: 4 March 1933. This last date confuses the creation with the birthday - 4 March—of Bishop Lladoc. Cf. $h t t p: / / w w w . c b c p n e w s . c o m / ? q=n o d e / 622$. The websites of the Diocese of Bacolod "The Student Catholic Action of the Philippines," and the catholic.ierarchy.org agree with the Augustinian Recollect chronicles: 15 July 1932. Cf. http://www.dioceseofbacolod.org.ph/pages/historicalhi.html and http://www.scaphilippines.com/ bacolod.html and https://www.catholic-hierarchy.org/diocese/ dbaco.html. Accessed 3 November 2015.

2 The word "bacolod" means "hill" or "bank of stone" probably from the town called "Daanbanua" located three or four kilometers towards the barrio of Granada. Bacolod was founded in or about 1770. It was then transferred to its present site. Marcellán, however, stated in 1879 that Bacolod was founded in 1756. The natives of the place and families from Iloilo and Antique settled in the old site of Bacolod. Avellaneda avers that 1788 was the foundation year of Bacolod as a town. He confessed he could find no record of the date of its creation as a parish. In a parochial book of Binalbagan, however, Avellaneda saw an entry of 11 January 1802 where Father Eusebio Lauren signed as curate of Bacolod. In the Cosas notables de Bacolod, the Recollect parish Francisco Vega claims that Bacolod was founded as a parish in 1802. See Emmanuel Luis A. Romanillos, Events in Bacolod, Negros Occidental, in the Parish Chronicle of (1871-1909) of Fr. Mauricio Ferrero, OAR, and Other Essays (Bacolod 2016) 53. 
Through his apostolic delegate in the Philippines, the Roman Pontiff appointed the then vicar general of the Diocese of Naga, Msgr. Casimiro Lladoc as bishop to govern the new ecclesiastical territory on 23 June 1933. ${ }^{3}$ Msgr. Lladoc had a Licentiate in Canon Law and was a professor at the University of Santo Tomas. He was born in Pilar, Sorsogon, on 4 March 1893, and received the holy presbyterate on 25 March 1918.

Together with Bishop James Paul McCloskey (1870-1945) of Jaro in Iloilo and Bishop Francisco Javier Reyes (1876-1937) of Nueva Caceres as co-consecrators, the Apostolic Delegate Archbishop Guglielmo Piani (1875-1956) consecrated Casimiro Lladoc as bishop on 16 September 1933 in Manila. ${ }^{4}$

\subsection{Recollects cede Negros parishes to the secular clergy}

Soon after Bishop Lladoc's episcopal consecration, which was celebrated with much pomp, the Recollect superiors in Manila paid him their respects and asked him what he wanted. The bishop believed it was opportune to replace our priests in Bacolod with native clergy. And this was no sooner said than done. When the people in Negros saw that the Recollects broke camp by simply withdrawing themselves, some town leaders filed petitions and even registered their protests with the highest authorities. Bacolod ${ }^{5}$, and several adjoining towns were under the Recollect administration. They owed almost everything to the Recollect Order. However, how erroneous were a great number of Christians! The Catholic missionary and his cause were more sublime: The ideal of religious orders was not circumscribed to a single territory!

The horizons of the Augustinian Recollect Order were not fundamentally linked to Bacolod, nor to five, nor to ten towns, although these towns-such as those of Negros-might be of such a great significance and so much glorious history for us. Without any trace of a doubt, to have prepared conveniently the apostolic vicariates - so lowly and so impoverished - and dioceses that were relatively opulent and of high morale like that of Negros, was an honor and splendor for the apostolic Province of Saint Nicholas of Tolentino.

Hence, since 1932 when the diocese was created, our confreres in Negros with all smiles advised and instructed the people in obedience, this axis of Catholicism, especially in the Philippines. The fears vanished, and the Recollects campaigned ceaselessly so that the new bishop would be welcomed in his diocese. It happened appropriately: with the pomp and majesty fit for a prince, with affection and enthusiastic applause.

\subsection{Ecclesiastical entourage from Manila sails to Negros in October 1933}

The prelates of the Church in the Philippines were then in Manila. When their conferences were done, they expressed their desire to honor Bishop Casimiro M. Lladoc by accompanying him to Negros. Among those appointed for the entourage was Vicar Provincial Leoncio Reta, who kindly invited Father Miguel Avellaneda to join the trip and accompany him to Negros. This was a fine occasion for the historian to visit the two provinces and almost all the Recollect curacies.

The church entourage left Manila on 23 October onboard the steamer Bohol. It was the following day, 24 October, when the waiting welcome party caught sight of the ship from the Silay wharf. Another steamer Princesa de Negros where the welcome committee was on board, met the prelates from Manila. They then transferred to the Princesa de Negros, which had docked at the Silay wharf, and from there, the waiting convoy of cars led the entourage to the new Church of Silay. They made a brief stop there, visited the Blessed Sacrament, and went on their way to Talisay.

The convoy of vehicles was already a kilometer long. Long before the arrival in Talisay, the Recollect priests had prepared the crowds in an orderly manner. From time to time, hurrahs and congratulations reverberated along the way. The crowds grew bigger and bigger until there was hardly any space to walk anymore. The entourage members got down from their cars. The papal delegate, the archbishop, and other prelates under the pallium proceeded to the parish church of Talisay amidst hymns and loud shouts of "Long live!" At the Talisay church portal was the parish priest Father Luis Alvarez OAR with the fluvial cape and almost all the Augustinian Recollect parish priests of

\footnotetext{
${ }^{3}$ For more on Bishop Lladoc, visit http://www.catholic-hierarchy.org/bishop/blladoc.html.

${ }^{4}$ After eighteen years as bishop of Bacolod, the prelate passed away on 24 October 1951 at the age of 58 . He was succeeded by Bishop Manuel P. Yap (1900-1966), Bishop of Capiz (1951-1952).

${ }^{5}$ The word "bacolod" means "hill" or "bank of stone" probably from the town called "Daanbanua" located three or four kilometers towards the barrio of Granada. Bacolod was founded in or about 1770. It was then transferred to its present site
} 
Negros Island. They came to pay their respects to the new bishop. The rite was so lavish that the Holy Father's apostolic delegate, emotionally touched, also addressed the Catholic congregation of Talisay.

\subsection{Bishop Lladoc takes possession of Bacolod}

The entourage continued the trip to Bacolod. But the downpour which commenced to fall scattered the crowds, so much so that when the entourage reached Bacolod, the dignitaries could not get out of the cars without getting drenched. The ceremonies which should have been celebrated at the town square had to be cancelled. At once, we headed for the parish church —now the cathedral-, there the papal bulls were read before the people who filled the naves to the rafters, and the $T e$ Deum hymn was sung. Shortly afterward, Bishop James Paul McCloskey of Jaro, Bishop Lladoc, and Archbishop Guglielmo Piani took turns reading their messages before the congregation. That night a popular banquet was held.

The following day, the new prelate celebrated the Pontifical Mass. Afterward, we had another sumptuous meal, which was hosted this time by the diocesan and regular clergy of the diocese for their local ordinary at the activity hall of La Consolacion College. During the two meals, speechesin a bombastic manner-were delivered. Nonetheless, endless silly orations, though done in good faith, were not wanting either. But it was a memorable event for Bacolod as the Christian community welcomed its first bishop.

\subsection{Land area of the new diocese}

According to the 1905 data from the Census Office of the United States of America, Negros Occidental had a land area of 3,130 square miles. ${ }^{6}$ Its total population was $308,272 .{ }^{7}$ Very sparsely populated, the western province had 98 inhabitants per square mile. Negros Oriental had a land area of 1,864 square miles. Its population was 201,494. In 1903, the Christian population of the two Negros provinces was $201,047.8$ The whole Negros was $208 \mathrm{kms}$. long and $80 \mathrm{kms}$. wide. The total land area was 12,642 sq. kms. The total population (1903) of eastern Negros was approximately 488,000 .

Siquijor, the sub-province of Negros Oriental, which likewise belonged to the new diocese, was $27 \mathrm{kms}$. long from west-northwest to east-southeast and twenty kms. long from north to south. The population of Siquijor was approximately 12,500 .

${ }^{6}$ Bacolod Diocese has 2,019 sq. miles only in the wake of creating the two Negros Dioceses of San Carlos and Kabankalan on 30 March 1987.

${ }^{7}$ The total population of the Philippines was 7,635,000, according to the Summary of Principal Vital Statistics of the Philippines, 1903-1997.

${ }^{8}$ The 2016-2017 Catholic Directory of the Philippines (page 9) listed the Catholic population of Bacolod Diocese as 1,089,128 from $1,396,318$. 


\section{SOURCES AND BIBLIOGRAPHY}

\section{Books}

Dennis V. Madrigal [ed.]. Handurawan. Visita Iglesia Negros y Recoletos. Bacolod City 2006.

_. Emmanuel Luis A. Romanillos. Padre Mauricio Ferrero, OAR (1844-1915): Father and Builder of Bacolod. Bacolod City 2016.

Patricio Marcellán. La Provincia de San Nicolás de Tolentino de los Agustinos Descalzos de la Congregación de España e Indias. Manila 1879.

Ángel Martínez Cuesta. History of Negros. Manila 1980.

Emmanuel Luis A. Romanillos. Events in Bacolod, Negros Occidental, in the Parish Chronicle of (1871-1909) of Fr. Mauricio Ferrero, OAR, and Other Essays. Bacolod 2016.

Modesto P. SAO-NOY. A Brief History of the Church in Negros Occidental. Bacolod City, 1976.

\section{Unpublished Papers}

Ángel Martínez Cuesta. Fuentes para un historia de la época posrevolucionaria de Bacolod, Negros Occidental. Roma, Italia 2016 (Typescript)

Jorr S. RaBACAL. The Contributions of Padre Mauricio Ferrero (1844-1915) to the Local Church of Bacolod, Negros Occidental. MA in Theology, Major in Church History Thesis. Recoletos School of Theology. Quezon City, 2016.

\section{Translator's Correspondence:}

EMMANUEL LUIS A. ROMANILLOS

elaromanillos@gmail.com

Mobile: (+63) 09228487395

Tel. No.: (02) 793-333-59 